\title{
Device Available For Evaluation Indicator
}

National Cancer Institute

\section{Source}

National Cancer Institute. Device Available For Evaluation Indicator. NCI Thesaurus. Code C93803.

Specifies whether or not the medical device is accessible for assessment by the manufacturer. 